\title{
PENGUJIAN VALIDITAS DAN RELIABILITAS SKALA IDENTITAS SOSIAL
}

\author{
Christiany Suwartono*1, Clara Moningka ${ }^{2}$ \\ ${ }^{1}$ Fakultas Psikologi, Universitas Katolik Indonesia Atma Jaya, \\ Jl. Jenderal Sudirman 51, Jakarta. 12930. \\ ${ }^{2}$ Fakultas Psikologi, Universitas Pembangunan Jaya. \\ Jl. Cendrawasih Raya Blok B7/P Bintaro Jaya, Sawah Baru, Ciputat, \\ Tangerang Selatan 15413 \\ *christiany.suwartono@atmajaya.ac.id
}

\begin{abstract}
Social identity is an essential part of individual's self-concept in the context of a particular group of his/her social environment. The social environment in this study referred to Indonesian as a nation. The authors adapted the Collective Self-Esteem Scale (CSE) from Luhtanen and Crocker to identify social identity; to detect to the extent that individual recognizes themselves as Indonesian as a nation. In this research, the scale is called as Social Identity Scale. A total of 298 participants of this study were Jakarta residents with a minimum education of High School or equivalent. For validation purpose, the analysis used Confirmatory Factor Analysis (CFA), using measurement model. The reliability testing used Cronbach's alpha and Omega coefficients. The results of this study indicate the Social Identity Scale in the context of Indonesian has four factors as CSE scale (Luhtanen \& Crocker, 1992) and reliable.
\end{abstract}

Keywords: factor analysis, Indonesia, reliability, social identity, validity

\begin{abstract}
Abstrak
Identitas sosial merupakan bagian penting dari konsep diri individu sebagai bagian dari kelompok tertentu dalam lingkungan sosialnya. Lingkungan sosial yang dimaksud pada penelitian ini adalah bangsa Indonesia. Peneliti melakukan adaptasi skala Collective Self-Esteem (CSE) dari Luhtanen dan Crocker yang dapat mengidentifikasikan identitas sosial yaitu sejauh mana individu mengidentifikasikan dirinya sebagai bagian dari bangsa Indonesia. Dalam penelitian ini, skala tersebut kemudian diberi judul Skala Identitas Sosial. Partisipan penelitian ini adalah penduduk Jakarta berjumlah 298 orang dengan pendidikan minimal Sekolah Menengah Atas atau sederajat. Pengujian validitas konstruk dilakukan dengan teknik Confirmatory Factor Analysis (CFA), khususnya dengan measurement model. Pengujian reliabilitas dilakukan melalui koefisien Cronbach's alpha dan koefisien Omega. Hasil penelitian ini menunjukkan skala Identitas Sosial dalam konteks bangsa Indonesia ini memiliki empat faktor sesuai dengan skala CSE dan reliabel.
\end{abstract}

Kata kunci: faktor analisis, identitas sosial, Indonesia, reliabilitas, validitas. 


\section{Pendahuluan}

Indonesia memiliki banyak sumber daya manusia dengan latar keberagaman yang luar biasa. Hal ini merupakan tantangan yang perlu dikelola dengan baik. Adanya kemajuan teknologi, terutama internet, mempercepat bahkan mendorong terjadinya pertukaran produk, pemikiran, bahkan kebudayaan lintas negara dengan lebih cepat; batas-batas antarnegara pun memudar. Hal inilah yang menjadi tantangan besar bagi diri dan lingkungan dalam membentuk identitas di tengah cepatnya perubahan di era ini. Dalam menghadapi perubahan ini, Indonesia membutuhkan sumber daya manusia yang menyadari afiliasi nasional untuk menjaga kesatuan dalam keberagaman yang ada. Afiliasi nasional ini merupakan awal dari identitas nasional. Mavric (2014) mendefinisikan identitas nasional sebagai suatu tipe dari identitas sosial yang berasal dari perasaan bahwa dirinya merupakan bagian dari bangsa tertentu sekaligus mengidentifikasikan dirinya dengan bangsa tertentu.

Identitas sosial merujuk pada sejauh mana individu merasa dirinya menjadi bagian dari suatu kelompok (Tougas \& Beaton, 2002). Lebih lanjut, Tougas dan Beaton (2002) menjelaskan bahwa meski individu dapat masuk dalam kelompok-kelompok tertentu, individu tersebut akan lebih terikat pada satu kelompok dibandingkan dengan kelompok yang lain. Hal ini yang menyebabkan identitas sosial erat kaitannya dengan perasaan deprivasi. Deprivasi merupakan determinan dalam menentukan identitas sosial seseorang. Petta dan Walker (1992) menjelaskan bahwa individu akan cenderung mengidentifikasikan dirinya dengan kelompok yang tidak memberikan perasaan deprivasi. Identifikasi ini berpengaruh terhadap bagaimana individu memandang kelompoknya, dengan perkataan lain terhadap harga diri kelompok. Hal ini selaras dengan penjelasan dari Tajfel dan Turner (1979) yang menyatakan ketika individu mengidentikasikan dirinya dalam kelompok sosial tertentu, individu cenderung akan melakukan evaluasi dan mengembangkan harga dirinya. Tajfel (1981) juga mengemukakan bahwa identitas sosial merupakan bagian dari konsep diri individu. Konsep diri yang kemudian berkembang menjadi harga diri kolektif ini diperoleh dari pengetahuannya selama berinteraksi dengan kelompok sosialnya dimana individu merasa bernilai dan memiliki ikatan emosional. Individu pun perlu mengembangkan perasaan positif tidak hanya pada identitas pribadi, namun juga identitas sosialnya.

Luhtanen dan Crocker (1992) menciptakan skala evaluasi diri yang mengukur identitas sosial dari seseorang. Mereka menemukan bahwa ada empat aspek dari identitas sosial, yaitu keanggotaan, publik, pribadi, dan identitas. Aspek pertama, keanggotaan menekankan rasa keberhargaan individu ketika ia menjadi bagian dari suatu kelompok. Aspek kedua, publik menekankan persepsi individu mengenai penilaian orang lain terhadap kelompoknya. Aspek ketiga, pribadi menekankan evaluasi pribadi sebagai bagian dari kelompoknya. Kemudian, terakhir, identitas menekankan keberartian keanggotaan tersebut bagi konsep dirinya. Skala evaluasi diri dari Luhtanen dan Crocker (1992) ini menjadi dasar pengembangan skala identitas nasional seperti yang sudah dilakukan oleh Lilli dan Diehl (1999).

Pada penelitian ini, peneliti tertarik untuk melakukan adaptasi untuk mengukur identitas sosial pada level individu di Indonesia. Adapun identitas sosial yang dimaksud dalam penelitian ini adalah sejauhmana individu mengidentifikasi dirinya sebagai bagian dari bangsa Indonesia. Skala yang dibahas dalam penelitian ini diberi nama Skala Identitas Sosial. Skala ini merupakan hasil adaptasi skala Collective Self-Esteem (CSE) dari Luhtanen dan Crocker (1992). Meskipun sudah ada hasil adaptasi dari CSE 
ini, namun skala yang dapat digunakan untuk mengukur identitas sosial ini, belum terbukti validitas dan reliabilitasnya.

Penelitian ini berfokus untuk melakukan uji validitas dan reliabilitas skala hasil adaptasi dari Luhtanen dan Crocker (1992). Hasil dari adaptasi ini diharapkan dapat menjadi masukan dalam memetakan masalah berkenaan dengan identitas nasional guna mengelola identitas nasional dan keberagaman yang ada di Indonesia. Adanya skala ini diharapkan dapat berguna untuk memberi informasi mengenai deskripsi identitas sosial dalam ranah penelitian sosial kemasyarakatan, juga untuk kepentingan penelitian selanjutnya di bidang psikologi sosial. Identitas sosial menjadi penting karena merupakan bagian dari identifikasi diri individu dan menggambarkan bagaimana individu mengkategorikan dirinya. Identitas ini merupakan salah satu elemen penting dalam pembentukan konsep diri (Tajfel \& Turner, 1986). Dengan demikian, masalah dalam penelitian ini adalah "Apakah skala Identitas Sosial ini valid dan reliabel?" Untuk menjawab permasalahan itu, peneliti menggunakan studi kuantitatif dengan desain nonexperimental jenis penelitian confirmatory factor analysis. Peneliti akan menganalisa struktur faktor yang ada pada alat ukur hasil adaptasi CSE, yaitu skala Identitas Sosial. Ada pun pendekatan yang digunakan adalah measurement model. Sampel dalam penelitian ini adalah penduduk Indonesia yang tinggal di sekitar Jakarta (minimal telah menempuh pendidikan sekolah menengah). Dengan pendidikan minimal SMA, mereka dianggap cukup memiliki pengalaman untuk memahami, mengikuti, dan dapat menempatkan dirinya pada kontinuum poin-poin yang tersedia pada alat ukur berskala Likert.

\section{Metode Penelitian}

Penelitian ini menggunakan teknik convenience sampling, dengan area penelitian tersebar di lima kotamadya Jakarta. Penggunaan sampel besar dalam pendekatan kuantitatif dianggap akan menghasilkan perhitungan statistik yang lebih akurat dan kemungkinan terpilihnya sampel devian lebih kecil dibandingkan menggunakan sampel kecil. Jumlah partisipan dalam penelitian ini adalah 298 partisipan. Sebagian besar partisipan berdomisili di area Jakarta Barat (36,90\%), Jakarta Selatan (16,80\%), Jakarta Timur (15,80\%), Jakarta Utara $(15,40 \%)$, dan Jakarta Pusat $(15,10 \%)$. Usia partisipan dibagi menjadi tiga kelompok: usia 20 - 37 tahun $(45,60 \%)$, 38 - 52 tahun $(32,90 \%)$, dan 53 tahun ke atas (21,50\%). Partisipan memiliki latar belakang pendidikan minimal SMA atau sederajat (16,10\%), D3 (0,3\%), S1 (50,70\%), S2 (30,50\%), dan S3 (2,30\%). Sebagian besar partisipan berprofesi sebagai karyawan swasta $(41,30 \%)$, staf pengajar $(17,10 \%)$, dan mahasiswa $(6 \%)$.

Peneliti melakukan adaptasi skala Collective Self-Esteem (CSE) dari Luhtanen \& Crocker (1992) menjadi Skala Identitas Sosial. Skala ini berisi 16 pernyataan dengan 7 pilihan jawaban dari sangat tidak setuju (dengan skor 1) sampai dengan sangat setuju (dengan skor 7). Dalam adaptasi ini, tidak ada pernyataan yang unfavorable. Kata "kelompok sosial" dalam pernyataan aitem, selalu diubah menjadi bangsa Indonesia atau Indonesia. Penelitian Luhtanen dan Crocker (1992) menemukan empat domain, yaitu keanggotaan (No. 1, 5, 9, dan 13), pribadi (No. 2, 6, 10, dan 14), publik (No. 3, 7, 11, dan 15), dan identitas (No. 4, 8, 12, dan 16). Domain keanggotaan mengukur sejauh mana rasa keberhargaan individu menjadi anggota pada suatu kelompok sosial tertentu. 
Domain pribadi mengukur evaluasi individu sebagai bagian dari kelompok sosial tertentu. Domain publik mengukur kepercayaan individu akan evaluasi orang lain terhadap kelompok sosialnya. Kemudian, domain identitas mengukur keberartian akan keanggotaan suatu kelompok sosial tertentu bagi konsep dirinya. Dalam konteks adaptasi skala ini, kelompok yang dimaksud adalah bangsa Indonesia dan diri sebagai warga negara Indonesia.

Guna mendapatkan alat tes yang baik, perlu dilakukan uji reliabilitas dan validitas. Reliabilitas adalah seberapa jauh suatu alat ukur memberikan hasil yang relatif tidak berbeda bila dilakukan pengukuran kembali terhadap gejala yang sama pada waktu yang berbeda (Anastasi \& Urbina, 1997). Dalam pengertian yang paling luas, reliabilitas alat ukur menunjukkan sejauh mana perbedaan-perbedaan individual dalam skor tes disebabkan oleh perbedaan-perbedaan yang sesungguhnya dalam aspek yang diukur dan sejauh mana dapat dianggap disebabkan oleh kesalahan peluang. Metode perhitungan yang digunakan adalah koefisien alpha, yang juga merupakan metode yang paling populer digunakan untuk mengukur konsistensi internal (Murphy \& Davidshofer, 2001). Peneliti juga melakukan analisis reliabilitas dengan koefisien Omega. Analisis reliabilitas dengan koefisien Omega, mengikuti langkah-langkah dalam Peters (2014). Metode Omega menggunakan pendekatan analisis faktor. Koefisien ini menekankan pada seberapa jauh aitem-aitem merefleksikan faktor laten yang disusun. Batasan koefisien reliabilitas yang baik menurut Anastasi dan Urbina (1997) berkisar 0,80 0,90. Setelah koefisien reliabilitas didapatkan, peneliti mencari nilai standard error of measurement. Hal ini dikarenakan kekonsistenan hasil pengukuran juga dipengaruhi oleh kesalahan-kesalahan dalam pengukuran, nilai standard error of measurement dibutuhkan guna mengestimasi skor tes yang mungkin diperoleh seseorang (Crocker \& Algina, 2008).

Pengujian selanjutnya adalah uji validitas. Validitas adalah sejauh mana alat ukur tersebut dapat mengukur hal yang mau diukur (Anastasi \& Urbina, 1997). Validasi dilakukan dengan metode Confirmatory Factor Analysis (CFA) dengan cara measurement model. Peneliti menguji dua model. Model yang pertama (Model a) adalah model awal oleh Luhtanen dan Crocker (1992) tanpa ada modifikasi. Kemudian model kedua (Model $b$ ), merupakan modifikasi dari Model $a$. Untuk menentukan model fit, $\mathrm{Hu}$ dan Bentler (1999) menyarankan Tucker-Lewis Index (TLI = NNFI) dan Comparative Fit Index (CFI) sama atau di atas 0,95. Sedangkan untuk menentukan struktur model yang adekuat dengan menggunakan nilai Akaike's Information Criterion (AIC; Akaike, 1987) yang terkecil dari model-model yang ada. Kemudian, dari Netemeyer, Bearden, dan Sharma (2003) menambahkan nilai $p$ dari chi square $\left(\chi^{2}\right)$ yang lebih besar dari 0,05; Goodness of Fit Index (GFI) yang lebih besar atau sama dengan 0,90; Root Mean Square Error of Approximation (RMSEA) lebih kecil atau sama dengan 0.08. Untuk nilai RMSEA lebih besar atau sama dengan 0,10 menandakan bahwa model tidak dapat diterima.

\section{Prosedur}

Pengambilan data dilakukan pada bulan Desember 2016 - September 2017. Pengambilan data dilakukan dengan metode daring. Tautan kuesioner disebarkan ke berbagai komunitas di Jakarta, seperti universitas-universitas yang tergabung dalam Konsorsium Psikologi Ilmiah Nusantara (KPIN) yang berdomisili di Jakarta: Universitas Persada Indonesia YAI, Universitas Bhayangkara Jakarta Raya, Universitas 
Muhammadiyah Prof. DR. HAMKA, Universitas Borobudur, Universitas YARSI, Universitas Al Azhar Indonesia, Universitas Bunda Mulia, Universitas Pembangunan Jaya, Universitas Pancasila, Universitas Tama Jagakarsa, dan Universitas Mercubuana. Kemudian, pengambilan data juga dilakukan di Universitas Gunadarma, Universitas Indonesia, Universitas Atma Jaya, dan Asosiasi Penyelenggara Perguruan Tinggi Psikologi Indonesia (AP2TPI) Jakarta, serta pada masyarakat umum.

Peneliti mendapatkan 300 partisipan, namun setelah dilakukan pengecekan, ada 2 isian kuesioner yang isiannya lebih dari 80\% bahkan mencapai $100 \%$ menjawab sangat tidak setuju pada semua pernyataan. Dengan demikian, 2 isian ini tidak dimasukkan dalam perhitungan, sehingga data yang diolah adalah 298. Analisis statistik dilakukan dengan bantuan program olah data. Peneliti menggunakan program IBM SPSS Statistics 22 dalam melakukan EFA dan analisis reliabilitas dengan Cronbach's alpha. Kemudian LISREL 8.80 untuk melakukan CFA. Analisis reliabilitas dengan menggunakan koefisien Omega dilakukan dengan program $\mathrm{R}$ dengan paket user friendly science (Peters, 2014).

\section{Hasil dan Pembahasan}

Dalam uji reliabilitas, besar sampel yang digunakan sejumlah 298 partisipan. Hasil analisis reliabilitas dengan teknik Cronbach's Alpha menghasilkan 0,94 $(M=$ $87,86, S D=14,41$ ) untuk 16 pernyataan Skala Identitas Sosial. Berdasarkan Kaplan dan Saccuzzo (2013), alat tes ini reliabel karena koefisien Alpha Cronbach yang dihasilkan di atas 0,70. Jangkauan koefisien corrected item-total correlation dari 16 pernyataan ini adalah 0,60 - 0,80 (Median =0,67). Peneliti mencari nilai standard error of measurement untuk mengestimasi jangkauan skor skala Identitas Sosial yang mungkin diperoleh seseorang. Adapun estimasi yang dihasilkan pada tingkat kepercayaan 68\% adalah $\pm 3,53$ dari skor total yang diperoleh dengan menggunakan Skala Identitas Sosial. Hal ini berarti, jika seseorang mendapatkan skor total Skala Identitas Sosial $=50$, maka dengan tingkat kepercayaan $68 \%$, estimasi skor yang sebetulnya bisa diperoleh orang tersebut antara 46,47 sampai 53,53. Tabel 1 menyajikan hasil reliabilitas per faktor dan total skala secara detil.

Tabel 1.

Reliabilitas per faktor dan total skala.

\begin{tabular}{llllllc}
\hline & Alpha & Omega & $\begin{array}{l}\text { Jangkauan } \\
\text { Korelasi Aitem- } \\
\text { Total }\end{array}$ & $\boldsymbol{M}$ & $\boldsymbol{S D}$ & $\begin{array}{l}\text { Jumlah } \\
\text { Pernyataan }\end{array}$ \\
\hline Keanggotaan & 0,81 & 0,82 & $0,50-0,71$ & 22,42 & 3,71 & 4 \\
Pribadi & 0,87 & 0,87 & $0,71-0,75$ & 23,11 & 3,98 & 4 \\
Publik & 0,87 & 0,87 & $0,66-0,77$ & 20,77 & 4,56 & 4 \\
Identitas & 0,86 & 0,87 & $0,60-0,79$ & 21,56 & 4,13 & 4 \\
\hline Identitas Sosial & 0,94 & 0,94 & $0,60-0,80$ & 87,86 & 14,41 & 16 \\
\hline
\end{tabular}

Hasil reliabilitas, khususnya dengan metode Cronbach's alpha menunjukkan pada setiap domain memiliki reliabilitas yang tinggi. Demikian pula dengan metode Omega pun menunjukkan bahwa skala Identitas Sosial ini reliabel. Hasil uji reliabilitas 
dengan menggunakan metode Cronbach's alpha pada penelitian kami lebih tinggi dibandingkan penelitian Luhtanen dan Crocker (1992), baik dalam reliabilitas per domain maupun total. Selain itu, jangkauan dari koefisien korelasi aitem-total per domain maupun total juga lebih tinggi dari penelitian Luhtanen dan Crocker (1992).

\section{Validitas}

Dalam validasi konstruk, peneliti melakukan Confirmatory Factor Analysis (CFA). Peneliti menguji dua model struktur faktor dari skala Identitas Sosial ini. Model a merupakan model dengan empat faktor, sesuai dengan alat ukur aslinya, CSE (Luhtanen \& Crocker, 1992). Hasil uji CFA model $a$ dapat dilihat pada Gambar 1 di bawah ini.

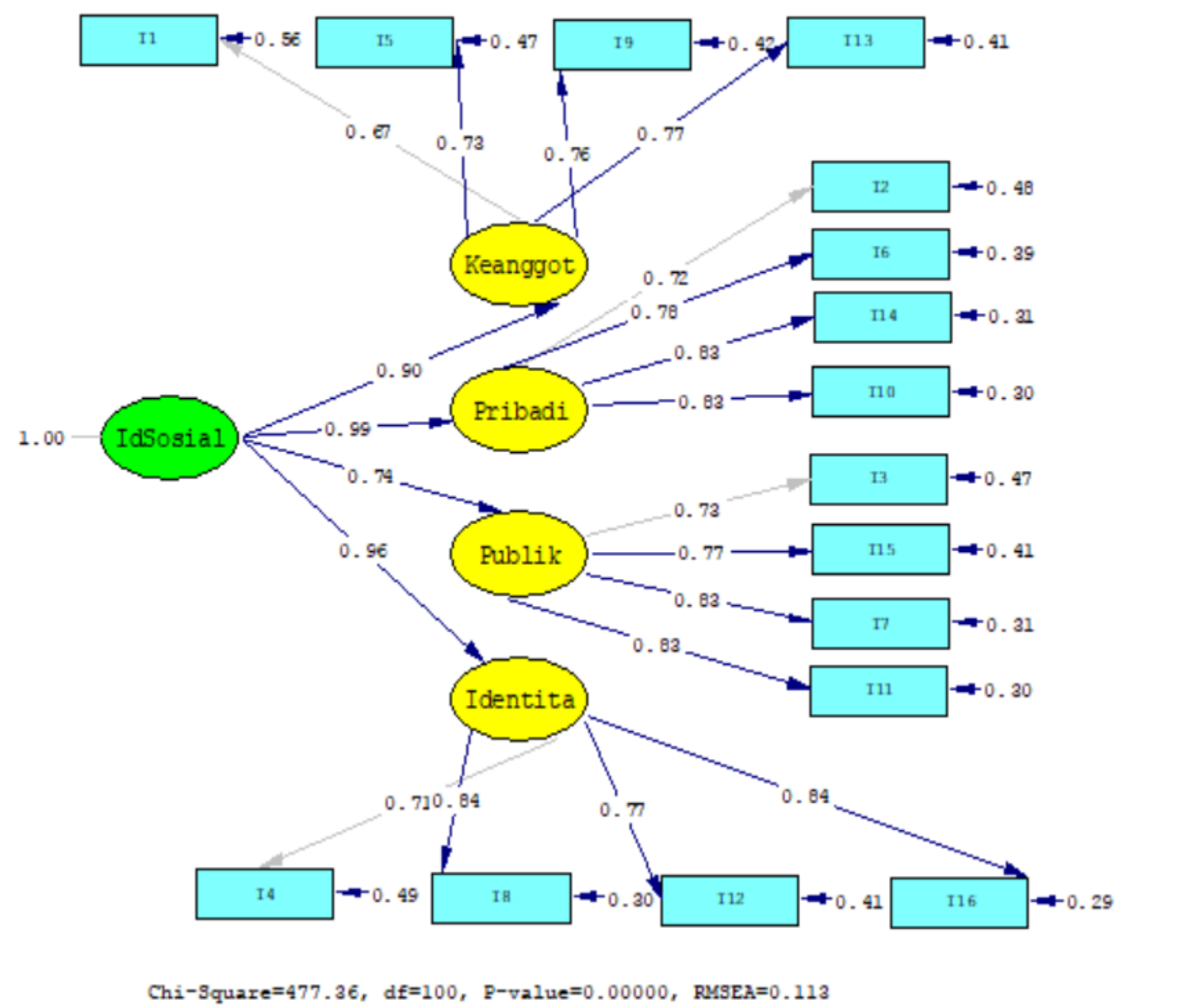

Gambar 1. Model awal (a) tanpa ada modification index.

Model $b$ merupakan model yang sama dengan Gambar 1, namun peneliti melakukan modifikasi indeks. Model $b$ dapat dilihat pada Gambar 2. 


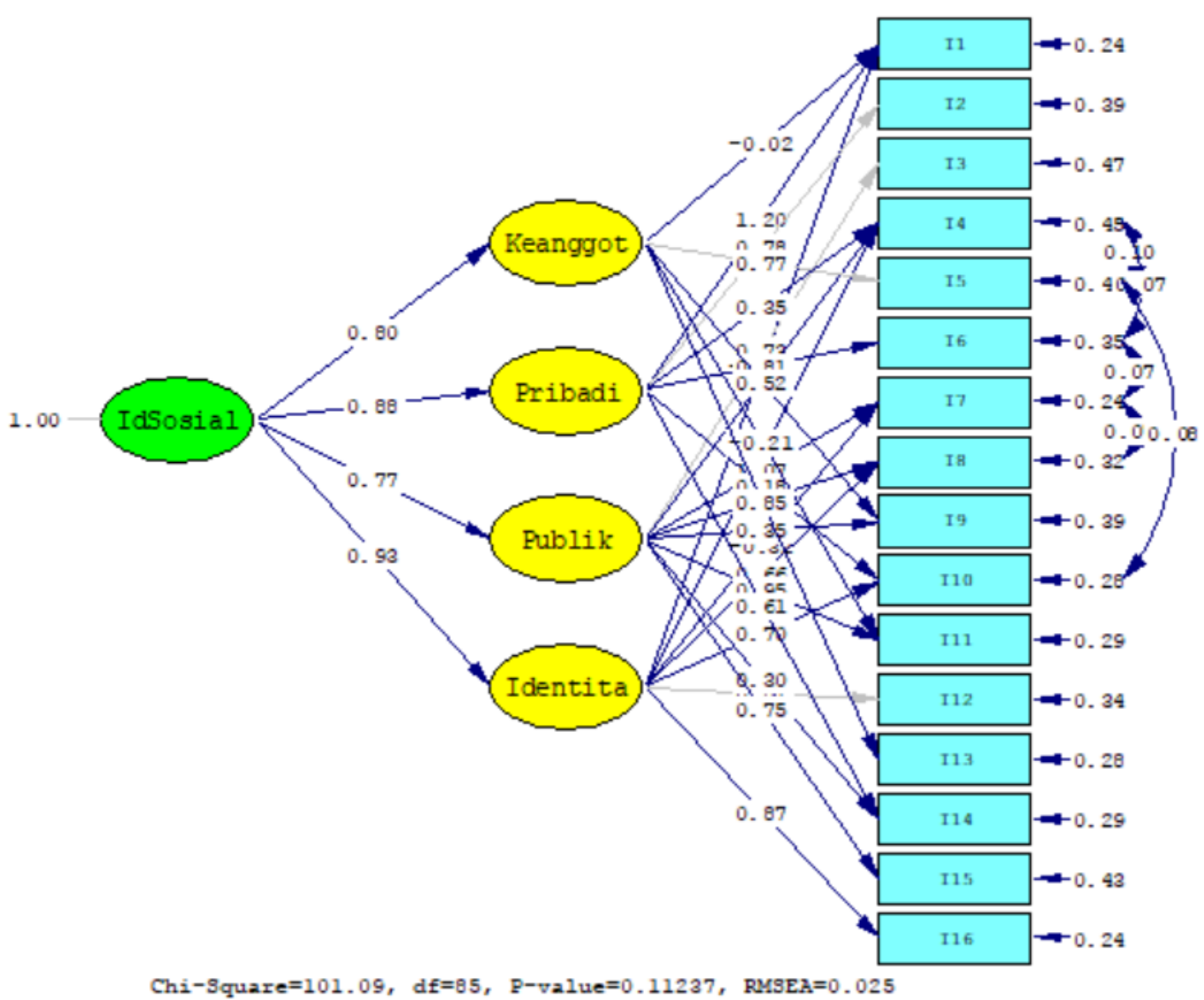

Gambar 2. Model fit (b) dengan ada 15 indeks yang dimodifikasi (modification index).

Susunan aitem-aitem dalam tiap domain cenderung tetap seperti skala CSE awal, namun ada beberapa aitem-aitem yang terpencar ke dalam satu sampai dua faktor lainnya. Lebih detil mengenai koefisien muatan faktor baik Model $a$ maupun Model $b$ dari tiap pernyataan aitem dapat dilihat pada Tabel 1 .

Tabel 1.

Koefisien Muatan Faktor $(\square)$ hasil analisis Confirmatory Factor Analysis

\begin{tabular}{|c|c|c|c|c|c|c|c|c|c|c|c|}
\hline \multirow[t]{2}{*}{ No. } & \multirow[t]{2}{*}{ Pernyataan } & \multicolumn{2}{|c|}{$\begin{array}{l}\text { Keanggo- } \\
\text { taan }\end{array}$} & \multicolumn{2}{|c|}{ Pribadi } & \multicolumn{2}{|c|}{ Publik } & \multicolumn{2}{|c|}{ Identitas } & \multicolumn{2}{|c|}{$\begin{array}{l}\text { Identitas } \\
\text { Sosial }\end{array}$} \\
\hline & & $a$ & $b$ & $a$ & $b$ & $a$ & $b$ & $a$ & $b$ & $a$ & $b$ \\
\hline 1 & $\begin{array}{l}\text { Saya merasa berharga } \\
\text { menjadi bagian dari } \\
\text { bangsa Indonesia. }\end{array}$ & .67 & -.02 & & 1.20 & & -- & & -.41 & .60 & .66 \\
\hline 5 & $\begin{array}{l}\text { Saya merasa banyak } \\
\text { yang dapat saya lakukan } \\
\text { untuk Indonesia. }\end{array}$ & .73 & .77 & & -- & & -- & & -- & .65 & .61 \\
\hline 9 & $\begin{array}{l}\text { Saya berpartisipasi aktif } \\
\text { dalam pembangunan } \\
\text { Indonesia. }\end{array}$ & .76 & .52 & & -- & & .35 & & -- & .69 & .68 \\
\hline 13 & $\begin{array}{l}\text { Saya merasa dapat } \\
\text { berguna bagi bangsa } \\
\text { saya. }\end{array}$ & .77 & .85 & & -- & & -- & & -- & .69 & .68 \\
\hline 2 & $\begin{array}{l}\text { Saya tidak pernah } \\
\text { menyesal menjadi }\end{array}$ & & -- & .72 & .78 & & -- & & -- & .71 & .69 \\
\hline
\end{tabular}




\begin{tabular}{|c|c|c|c|c|c|c|c|c|c|c|c|}
\hline \multirow[t]{2}{*}{ No. } & \multirow[t]{2}{*}{ Pernyataan } & \multicolumn{2}{|c|}{$\begin{array}{l}\text { Keanggo- } \\
\text { taan }\end{array}$} & \multicolumn{2}{|c|}{ Pribadi } & \multicolumn{2}{|c|}{ Publik } & \multicolumn{2}{|c|}{ Identitas } & \multicolumn{2}{|c|}{$\begin{array}{c}\text { Identitas } \\
\text { Sosial }\end{array}$} \\
\hline & & $a$ & $b$ & $a$ & $b$ & $a$ & $\boldsymbol{b}$ & $a$ & $\boldsymbol{b}$ & $a$ & $b$ \\
\hline & $\begin{array}{l}\text { Warga Negara } \\
\text { Indonesia. }\end{array}$ & & & & & & & & & & \\
\hline 6 & $\begin{array}{l}\text { Saya merasa bahagia } \\
\text { menjadi orang } \\
\text { Indonesia. }\end{array}$ & & -- & .78 & .81 & & -- & & -- & .77 & .72 \\
\hline 10 & $\begin{array}{l}\text { Menjadi bagian dari } \\
\text { bangsa Indonesia adalah } \\
\text { sesuatu yang berharga. }\end{array}$ & & -- & .83 & .18 & & - & & .70 & .83 & .81 \\
\hline 14 & $\begin{array}{l}\text { Saya merasa bangga } \\
\text { dengan bangsa } \\
\text { Indonesia. }\end{array}$ & & -- & .83 & .61 & & .30 & & -- & .82 & .77 \\
\hline 3 & $\begin{array}{l}\text { Secara umum, bangsa } \\
\text { Indonesia baik di mata } \\
\text { dunia. }\end{array}$ & & -- & & -- & .73 & .73 & & -- & .54 & .56 \\
\hline 7 & $\begin{array}{l}\text { Secara umum, orang } \\
\text { menganggap bangsa } \\
\text { Indonesia unggul } \\
\text { dibandingkan dengan } \\
\text { bangsa lain. }\end{array}$ & & -- & & - & .83 & 1.07 & & -.32 & .61 & .52 \\
\hline 11 & $\begin{array}{l}\text { Bangsa saya dihargai } \\
\text { oleh orang atau bangsa } \\
\text { lain. }\end{array}$ & & -.21 & & - - & .83 & .95 & & - - & .62 & .57 \\
\hline 15 & $\begin{array}{l}\text { Secara umum orang lain } \\
\text { berpendapat bahwa } \\
\text { bangsa Indonesia dapat } \\
\text { diperhitungkan di } \\
\text { kancah dunia. }\end{array}$ & & -- & & - - & .77 & .75 & & -- & .57 & .58 \\
\hline 4 & $\begin{array}{l}\text { Saya dapat merasakan } \\
\text { manfaat dengan menjadi } \\
\text { bagian dari bangsa } \\
\text { Indonesia. }\end{array}$ & & -- & & .35 & & .43 & $\begin{array}{l}.7 \\
1\end{array}$ & .02 & .68 & .66 \\
\hline 8 & $\begin{array}{l}\text { Menjadi bagian dari } \\
\text { bangsa Indonesia adalah } \\
\text { hal penting yang } \\
\text { menggambarkan siapa } \\
\text { saya. }\end{array}$ & & -- & & -- & & .21 & $\begin{array}{l}.8 \\
4\end{array}$ & .66 & .8 & .78 \\
\hline 12 & $\begin{array}{l}\text { Menjadi bagian dari } \\
\text { Indonesia } \\
\text { mempengaruhi } \\
\text { pembentukan diri saya. }\end{array}$ & & -- & & - - & & -- & $\begin{array}{l}.7 \\
7\end{array}$ & .81 & .74 & .76 \\
\hline \multirow[t]{5}{*}{16} & $\begin{array}{l}\text { Menjadi bagian dari } \\
\text { bangsa ini merupakan } \\
\text { hal yang penting bagi } \\
\text { gambaran diri saya. }\end{array}$ & & -- & & - & & -- & $\begin{array}{l}.8 \\
4\end{array}$ & .87 & .81 & .81 \\
\hline & & & & & & & \multicolumn{3}{|c|}{ Keanggotaan } & .90 & .80 \\
\hline & & & & & & & & \multicolumn{2}{|c|}{ Pribadi } & .88 & .88 \\
\hline & & & & & & & & \multicolumn{2}{|c|}{ Publik } & .77 & .77 \\
\hline & & & & & & & & \multicolumn{2}{|c|}{ Identitas } & .93 & .93 \\
\hline
\end{tabular}

Pada Tabel 1, khususnya berdasarkan hasil uji Model $b$, ditemukan bahwa beberapa aitem seperti aitem no. 1 yang seharusnya merupakan bagian dari faktor 
Keanggotaan, juga memiliki muatan faktor di faktor Pribadi dan Identitas. Selain itu, aitem no. 4 yang seharusnya merupakan bagian dari faktor Identitas, juga memiliki muatan faktor di faktor Pribadi dan Publik. Kemudian aitem no. 7, 8, 9, 10, 11, dan 14 juga memiliki muatan faktor di satu faktor yang berbeda dengan faktor awalnya. Detilnya dapat dilihat pada Tabel 2.

Tabel 2.

Analisis Muatan Faktor tiap Aitem

\begin{tabular}{|c|c|c|c|c|}
\hline Aitem & Faktor awal & Modification index & $\begin{array}{c}\text { Muatan } \\
\text { faktor } \\
\text { terbesar }\end{array}$ & Pernyataan \\
\hline 1 & 1 & 2 & 2 & \multirow[t]{3}{*}{$\begin{array}{l}\text { Saya merasa berharga menjadi bagian } \\
\text { dari bangsa Indonesia. }\end{array}$} \\
\hline 2 & 2 & & & \\
\hline 3 & 3 & & & \\
\hline 4 & 4 & 3 & 3 & \multirow[t]{6}{*}{$\begin{array}{l}\text { Saya dapat merasakan manfaat dengan } \\
\text { menjadi bagian dari bangsa Indonesia. }\end{array}$} \\
\hline 5 & 1 & & & \\
\hline 6 & 2 & & & \\
\hline 7 & 3 & 4 & 3 & \\
\hline 8 & 4 & 3 & 4 & \\
\hline 9 & 1 & 3 & 1 & \\
\hline 10 & 2 & 4 & 4 & \multirow[t]{7}{*}{$\begin{array}{l}\text { Menjadi bagian dari bangsa Indonesia } \\
\text { adalah sesuatu yang berharga. }\end{array}$} \\
\hline 11 & 3 & 1 & 3 & \\
\hline 12 & 4 & & & \\
\hline 13 & 1 & & & \\
\hline 14 & 2 & 3 & 2 & \\
\hline 15 & 3 & & & \\
\hline 16 & 4 & & & \\
\hline
\end{tabular}

Sebagian besar aitem-aitem yang memiliki muatan faktor di luar dirinya sendiri tetap memiliki muatan faktor terbesar terhadap dirinya sendiri, kecuali untuk aitem 1, 4, dan 10. Tiga pernyataan aitem ini memiliki muatan faktor terbesar dengan faktor lain sehingga hal ini menjadi temuan yang menarik untuk dibahas dari segi isi pernyataan. Aitem no. 1, yaitu "Saya merasa berharga menjadi bagian dari bangsa Indonesia" seharusnya merupakan bagian dari faktor Keanggotaan, justru memiliki muatan faktor terbesar di faktor Pribadi. Tampaknya ketika partisipan menjawab aitem ini, rasa berharga tidak hanya dipandang sebagai intensitas melainkan juga meliputi pertimbangan positif dan negatif dari posisinya sebagai kelopok sosial tertentu. Aitem no. 4, yaitu "Saya dapat merasakan manfaat dengan menjadi bagian dari bangsa Indonesia" seharusnya merupakan bagian dari faktor Identitas, justru memiliki muatan faktor terbesar di faktor Publik. Pada faktor Identitas, penekanan ada pada konsep diri partisipan sedangkan pada faktor Publik menitikberatkan akan kepercayaan individu terhadap pandangan orang lain ketika dirinya menjadi satu bagian dari kelompok sosial 
tertentu. Hal ini mengindikasikan bahwa perasaan partisipan mengenai rasa manfaat menjadi bagian dari suatu kelompok sosial tidak menjadi bagian konsep dirinya melainkan dari kepercayaan individu akan penilaian orang lain terhadap kelompok sosialnya. Kemudian aitem no. 10, yaitu "Menjadi bagian dari bangsa Indonesia adalah sesuatu yang berharga" seharusnya merupakan bagian dari faktor Pribadi, justru memiliki muatan faktor terbesar di faktor Identitas. Hal ini menandakan bahwa "menjadi bagian" dari suatu kelompok sosial ini berkontribusi dengan konsep diri dari partisipan. Dengan demikian, pada penerapan selanjutnya aitem 1, 4, dan 10 selain dipertimbangkan sebagai penyumbang faktor Keanggotaan, Identitas, dan Pribadi; juga dipertimbangkan sebagai bagian dari Pribadi, Publik, dan Identitas.

Adapun model yang fit dengan data mengenai struktur dari Skala Identitas Sosial ini dapat dilihat dalam Tabel 3.

Tabel 3.

Goodness-of-Fit Indices dari Hasil Confirmatory Factor Analysis

\begin{tabular}{lllllllll}
\hline $\begin{array}{l}\text { Model } \\
\text { Kriteria }\end{array}$ & $\chi^{2}$ & df & $\begin{array}{l}\boldsymbol{p} \text {-value } \\
>0,05\end{array}$ & $\begin{array}{l}\text { RMSEA } \\
<0,08\end{array}$ & $\begin{array}{l}\text { CFI } \\
\geq 0,95\end{array}$ & $\begin{array}{l}\text { AIC } \\
\text { terkecil }\end{array}$ & $\begin{array}{l}\text { TLI } \\
\geq 0,95\end{array}$ & $\begin{array}{l}\text { GFI } \\
\geq 0,90\end{array}$ \\
\hline$A$ & 447,36 & 100 & 0,00 & 0,11 & 0,96 & 549,36 & 0,93 & 0,83 \\
$B$ & 101,09 & 85 & 0,11 & 0,02 & 1.00 & 203,09 & 0,94 & 0,93 \\
\hline
\end{tabular}

Berdasarkan nilai $p$, RMSEA, koefisien CFI, dan GFI, peneliti mendukung Model $b$ sebagai model yang lebih adekuat daripada Model $a$. Selain itu, berdasarkan nilai AIC, peneliti menyimpulkan bahwa Model $b$ adalah model yang terbaik. Hasil uji validitas dengan teknik Confirmatory Factor Analysis (CFA) menunjukkan bahwa model empat faktor dengan beberapa modifikasi fit (adekuat) dengan data lapangan.

Ada pun korelasi antarfaktor dapat dilihat pada Tabel 4.

Tabel 4.

Hasil Korelasi Antar-Faktor dan Total

\begin{tabular}{lrrrr} 
& \multicolumn{1}{c}{ Keanggotaan } & Pribadi & Publik & Identitas \\
\hline Keanggotaan (1) & 1 & & & \\
Pribadi (2) & $.778^{* *}$ & 1 & & \\
Publik (3) & $.564^{* *}$ & $.631^{* *}$ & 1 & \\
Identitas (4) & $.743^{* *}$ & $.829^{* *}$ & $.666^{* *}$ & 1 \\
Identitas Sosial & $.864^{* *}$ & $.914^{* *}$ & $.827^{* *}$ & $.918^{* *}$ \\
\hline$* *$ Korelasi signifikan pada LoS 0,01 (dua arah) & & &
\end{tabular}

Korelasi antarfaktor juga memiliki hubungan yang sedang sampai kuat $(0,56-$ 0,83). Korelasi terkuat ditemukan antara faktor Identitas dengan Pribadi $\left(r_{(296)}=0,83, p\right.$ $<0,01)$. Hal ini menunjukkan bahwa evaluasi individu akan kelompok sosialnya berkaitan erat dengan konsep dirinya. Semakin positif evaluasi individu bahwa dirinya menjadi bagian dari kelompok sosial tertentu maka semakin bagus konsep dirinya dengan menjadi anggota di kelompok sosial tertentu, sedangkan yang terendah ditemukan antara faktor Keanggotaan dan Publik $\left(r_{(296)}=0,56, p<0,01\right)$. Hal ini menandakan rasa keberhargaan yang dirasakan berhubungan dengan persepsi akan evaluasi orang lain terhadap kelompok sosial seseorang. Penelitian Luhtanen dan Crocker (1992) pada skala ini dilakukan yang dilakukan di Amerika juga menunjukkan 
adanya interkorelasi yang signifikan antar faktor. Namun, berbeda dengan temuan peneliti, korelasi terkuat mereka temukan pada faktor Keanggotaan dan Pribadi, sedangkan yang terlemah adalah pada faktor Publik dan Identitas. Hal ini kemungkinan dikarenakan pengambilan data dilakukan di Jakarta pada saat proses pemilihan gurbernur. Pada periode tersebut; terutama saat-saat menjelang atau sesudah debat terbuka antar calon pemimpin DKI Jakarta situasi cenderung tidak stabil dan tentunya ada pihak yang puas dan tidak puas. Ketidakpuasan individu akan membuat individu melakukan evaluasi terhadap identitas sosialnya dan menampilkan perilaku yang sesuai dengan evaluasinya seperti memisahkan diri dari kelompok bahkan masuk ke dalam kelompok sosial yang baru (Tajfel \& Turner, 1979). Ketidakpuasan individu bisa berasal dari kompetensi (unjuk kerja atau status) dan moralitas kolektif (Branscombe, Ellemers, Spears, \& Doosje, 1999). Moralitas kolektif ini dipersepsikan individu berdasarkan bagaimana suatu negara memperlakukan individu atau negara lain (misalnya dalam kondisi perang, penjajahan, diskriminasi dalam pekerjaan) dan bagaimana suatu negara memperlakukan masyarakatnya sendiri (misalnya anggota kelompok minoritas).

Weinreich (1986) menjelaskan bahwa evaluasi individu terhadap kelompoknya berhubungan dengan keyakinan individu terhadap evaluasi orang lain terhadap kelompok sosial dimana individu menjadi anggota. Hubungan ini dapat dijelaskan dengan konsep dari Cooley (1956) yaitu reflected appraisal atau the looking glass self dalam pembentukan konsep diri. Hal ini dapat dilihat dengan adanya gerakan untuk lebih menghargai keberadaan kelompok kulit hitam dan homoseksual di Amerika. Kejadian ini menimbulkan dugaan bahwa hubungan antara faktor Publik dan Pribadi dalam dalam identitas sosial dapat dipengaruhi oleh perbedaan kelompok juga budaya (individualis dan kolektivis) dapat menyebabkan perbedaan interkorelasi antarfaktor.

Hasil uji validasi internal skala Identitas Sosial menggunakan teknik CFA fit dengan empat faktor. Korelasi antar faktor kemudian korelasi faktor dengan total menghasilkan koefisien korelasi yang positif dan signifikan. Kekuatan koefisien korelasinya pun termasuk sedang ke arah kuat. Hal ini berarti, semua faktor memiliki keterkaitan satu sama lain dalam mengukur identitas sosial. Skala Identitas Sosial, hasil adaptasi dari CSE ini memiliki validitas internal yang baik. Penelitian selanjutnya dapat menguji validasi eksternal dari skala ini.

\section{Simpulan}

Skala Collective Self-Esteem (CSE) ini telah kami adaptasi menjadi skala Identitas Sosial (IS) dalam konteks bangsa Indonesia dan diri sebagai warga negara Indonesia. Hasilnya skala ini memiliki struktur yag sama dengan CSE. Peneliti menemukan empat faktor, yaitu Keanggotaan, Pribadi, Publik, dan Identitas. Dalam penelitian ini, peneliti menguji reliabilitas dan validitas skala IS. Hasil reliabilitas, khususnya dengan metode Cronbach's alpha dan omega menunjukkan pada setiap domain memiliki reliabilitas yang tinggi. Hal ini menunjukkan bahwa skala IS ini reliabel. Kemudian hasil dari uji validitas konstruk dengan metode faktor analisis menemukan sekaligus mengkonfirmasi bahwa dengan data sampel dari Jakarta, peneliti menemukan bahwa skala Identitas Sosial ini adekuat dengan empat faktor. Dengan demikian, skala IS ini bisa digunakan dalam penelitian di area psikologi sosial, khususnya mengenai identitas sosial. 


\section{Daftar Pustaka}

Akaike, H. (1987). Factor analysis and AIC. Psychometrika, 52, 317-332.

Anastasi, A \& Urbina, S. (1997). Psychological testing. (7th Ed). Indiana: PrenticeHall, Inc.

Branscombe, N. R., Ellemers, N., Spears, R., \& Doosje, B. (1999). The context and content

of social identity threat. In N. Ellemers, R. Spears, \& B. Doosje (Eds.), Social identity: Context, commitment, content. Oxford: Blackwell.

Cooley, C.H. (1956). Human nature and the social order. New York: Free Press.

Crocker, L., \& Algina, J. (2008). Introduction to classical and modern test theory. Ohio, USA: Cengage Learning.

Hu, L.T., \& Bentler, P.M. (1999). Cut-off criteria for fit indexes in covariance structure analysis: Conventional criteria versus new alternatives. Structural Equation Modeling, 6(1), 1-55.

Kaplan, R. M., \& Saccuzzo, D. P. (2013). Psychological testing: Principles, applications, and issues. (8th ed.). Belmont, CA: Thomson Wadsworth.

Luhtanen, R., \& Crocker, J. (1992). A collective self-esteem scale: Self-evaluation of one's social identity. Personality and Social Psychology Bulletin, 18, 302-318.

Lilli, W. \& Diehl, M. (1999). Measuring National Identity. Working Paper, Nr. 10, Mannheimer Zentrum für Europäische Sozialforschung. Diunduh online 9 Februari 2017 pada http://www.mzes.uni-mannheim.de/publications/wp/wp10.pdf

Mavric, B. (2014). Psycho-social conception of National Identity and Collective SelfEsteem. Epiphany, 7(1), $184-200$.

Murphy, K. R., \& Davidshover, C. O. (2001). Psychological Testing: Principles and Applications. (5th Ed). New Jersey: Prentice Hall.

Netemeyer, R. G., Bearden, W. O., \& Sharma, S. (2003). Scaling Procedures: Issues and Applications. Thousand Oaks: SAGE Publications.

Peters, G. J. Y. (2014). The alpha and the omega of scale reliability and validity: Why and how to abandon Cronbach's alpha and the route towards more comprehensive assessment of scale quality. The European Health Psychologist, $16,56-69$.

Petta, G., \& Walker, I. (1992). Relative deprivation and ethnic identity. British Journal of Social Psychology, 31(4), 285-293. doi: 10.1111/j.20448309.1992.tb00973.x

Tajfel, H., \& Turner, J. C. (1979). An integrative theory of intergroup conflict. In W. G. Austin \& S. Worchel (Eds.), The social psychology of intergroup relations. Monterey, CA: Brooks-Cole.

Tajfel, H. (1981) Human groups and social categories: studies in social psychology. Cambridge, UK: Cambridge University Press. 
Tajfel, H., \& Turner, J. C. (1986). The social identity theory of intergroup behavior Dalam W. G. Austin \& S. Worchel (Eds.), The social psychology of intergroup relations. Chicago, IL: Nelson-Hall.

Tougas, F., \& Beaton, A.M. (2002). Personal and group deprivasi relatif: Connecting the "I" to the "We". Dalam I. Walker dan H.J Smith (Ed), Deprivasi relatif: specification, development and integration (119-135). Cambridge: Cambridge University Press.

Trepte, S. (2006). Social identity theory. Dalam J. Bryant \& P. Vorderer (Eds). Psychology of Entertainment. New Jersey: Lawrence Erlbaum.

Weinreich, P. (1986). The operationalization of identity theory in racial and ethnic relations. Dalam J. Rex \& D. Mason (Eds), Theories of race and ethnic relations. Cambridge: Cambridge University Press. 